\title{
Role of RadA and DNA Polymerases in Recombination-Associated DNA Synthesis in Hyperthermophilic Archaea
}

\author{
Gaëlle Hogrel ${ }^{1,2}$, Yang Lu ${ }^{1,2}$, Nicolas Alexandre ${ }^{1,2}$, Audrey Bossé ${ }^{1,2}$, Rémi Dulermo ${ }^{1,2}$, \\ Sonoko Ishino $^{3}$, Yoshizumi Ishino ${ }^{3}$ and Didier Flament ${ }^{1,2, *}$ \\ 1 Laboratoire de Microbiologie des Environnements Extrêmes, Ifremer, CNRS, University Brest, \\ 29280 Plouzané, France; gaelle.hogrel@ifremer.fr (G.H.); yang.lu@ifremer.fr (Y.L.); \\ alexandre.nicolas2@outlook.fr (N.A.); audrey.bosse@ifremer.fr (A.B.); remi.dulermo@ifremer.fr (R.D.) \\ 2 LIA1211 MICROBSEA, Sino-French International Laboratory of Deep-Sea Microbiology, \\ 29280 Xiamen-Plouzané, France \\ 3 Department of Bioscience and Biotechnology, Graduate School of Bioresource and Bioenvironmental \\ Sciences, Kyushu University, 744 Motooka, Nishi-ku, Fukuoka, Fukuoka 819-0395, Japan; \\ sonoko@agr.kyushu-u.ac.jp (S.I.); ishino@agr.kyushu-u.ac.jp (Y.I.) \\ * Correspondence: didier.flament@ifremer.fr
}

Received: 29 May 2020; Accepted: 9 July 2020; Published: 14 July 2020

\begin{abstract}
Among the three domains of life, the process of homologous recombination (HR) plays a central role in the repair of double-strand DNA breaks and the restart of stalled replication forks. Curiously, main protein actors involved in the HR process appear to be essential for hyperthermophilic Archaea raising interesting questions about the role of HR in replication and repair strategies of those Archaea living in extreme conditions. One key actor of this process is the recombinase RadA, which allows the homologous strand search and provides a DNA substrate required for following DNA synthesis and restoring genetic information. DNA polymerase operation after the strand exchange step is unclear in Archaea. Working with Pyrococcus abyssi proteins, here we show that both DNA polymerases, family-B polymerase (PolB) and family-D polymerase (PolD), can take charge of processing the RadA-mediated recombination intermediates. Our results also indicate that PolD is far less efficient, as compared with PolB, to extend the invaded DNA at the displacement-loop (D-loop) substrate. These observations coincide with previous genetic analyses obtained on Thermococcus species showing that PolB is mainly involved in DNA repair without being essential probably because PolD could take over combined with additional partners.
\end{abstract}

Keywords: homologous recombination; Archaea; DNA polymerase; recombinase; DNA repair

\section{Introduction}

The evolution has equipped the three domains of life, Bacteria, Archaea and Eukarya, with a faithful process to repair Double-Strand Breaks (DSB): Homologous Recombination (HR). This pathway restores genetic information by copying a homologous template sequence [1]. Other DSB repair pathways operate alongside HR: the Non-Homologous End-Joining (NHEJ) [2] and Alternative End-Joining (a-EJ) pathways [3]. Efficient and less energetically demanding, these two alternative pathways are however more error-prone processes as they can result in deletions. Components involved in NHEJ and a-EJ are inexistent or partially conserved in archaeal species in comparison to Bacteria and Eukarya [4].

In Archaea, HR pathway seems to have major functions not only for DSB repair, but also to initiate replication. In this regard, several genetic studies in Crenarchaeota and Euryarchaeota highlighted the essentiality of HR proteins (such as Mre11 and RadA) in hyperthermophilic Archaea where their 
deletion resulted in lethal phenotypes [5-7]. In the last decade, studies on archaeal strains deleted from replication origins, revealed the potential role of HR proteins to initiate DNA synthesis outside canonical origins [8,9]. In Haloferax volcanii, the four chromosomal origins (oriCs) can be deleted together from the genome without any growth defect, but the $\mathrm{radA}$ gene is essential in the oriC-less strain [8]. Together these observations raised interesting questions about the role of $\mathrm{HR}$ in replication strategies within the archaeal domain.

During the HR process, the DSB is detected and resected by exonucleases to generate $3^{\prime}$ single-stranded DNA (ssDNA) tails. This ssDNA will be the starting point for the search of a homologous sequence that could be used as a template to restore the lost genetic information. For the homology search, RecA-family recombinases are key proteins. Named RecA in Bacteria, Rad51 in Eukarya and RadA in Archaea [10,11], they all bind ssDNA in a manner that leads to the formation of a nucleoprotein filament (reviewed in [12]). Structural and biophysical analysis of the filamentous forms of the recombinase along DNA have revealed that the dynamic flexibility of Rad51 nucleoprotein filament is dependent on the binding and hydrolyzing of ATP molecules ([13-19]). Rad51 interacts with DNA through its phosphate backbone with two binding sites used to interact both with ssDNA and dsDNA allowing homology search. When this homologous sequence has been successfully found, the DNA strand exchange between the donor sequence and the recombinase filament leads to a specific structure, known as the displacement-loop (D-loop).

In the D-loop, a structure similar to a replication fork is formed. The invasive strand brought by the recombinase provides a primer with a $3^{\prime}$ end available for further $5^{\prime}$ to $3^{\prime}$ DNA synthesis by DNA polymerases. In Archaea, DNA polymerase operating after the strand exchange step has not been identified. To date, DNA-dependent DNA polymerases have been classified based on their primary structures into six families: A, B, C, D, X and Y. Previous biochemical studies have shown that several DNA polymerases are capable of DNA synthesis on recombination intermediates: (i) Pol IV (Y), Pol II (B) and Pol III (C) in Bacteria [20-22], (ii) Pol $\zeta$, Pol $\delta$, Primase/Pol $\alpha$ (B) and Pol $\eta$ (Y) in Eukarya [23-29]. A genetic system in yeast revealed that both replicative DNA polymerases, Pol $\delta$ and Pol $\varepsilon$, are required for HR [28], but the precise role of Pol $\varepsilon$ remains to be determined [29].

In Archaea, only three DNA polymerase families have been identified: B, D and Y (see reviews [30,31]). All Archaea contain family-B polymerase (PolB) structurally similar to eukaryotic replicative DNA polymerases [32,33]. The family-D represented by PolD [34] is more unusual as it presents functional properties of a replicative DNA polymerase but with a catalytic subunit sharing similarities with RNA polymerases [35]. PolD is widely distributed among Archaea, except the crenarchaeal organisms, but is never found in Bacteria and Eukarya. Finally, the family-Y DNA polymerase has been found only in Crenarchaea phylum [36].

Our study model, the hyperthermophilic euryarchaea, Pyrococcus abyssi, encodes three enzymes capable of DNA synthesis: PolB, PolD and the p41/p46 complex. The p41/p46 complex is involved in RNA primer synthesis but is also a potential DNA repair enzyme [37-40]. Several biochemical characterization studies contributed to show that both PolB and PolD are processive enzymes with high nucleotide selectivity and $3^{\prime}-5^{\prime}$ proofreading activities [32-34,39,41-46].

The functional role of PolB and PolD in DNA replication and/or DNA repair has been debated for a long time. Inspired by the respective role of Pol $\varepsilon$ and Pol $\delta$ in eukaryotic DNA replication in addition to biochemical studies such as primer usage and strand-displacement activity $[47,48]$, it has been suggested that PolB replicates the leading strand, whereas PolD replicates the lagging strand. In another side, gene deletion studies indicate that only PolD is required for DNA replication while PolB is important for DNA repair but not essential in Thermococcales [49-51]. What about their role in HR process in Archaea? Our understanding of the precise mechanisms by which DNA synthesis takes place during HR in Archaea is incomplete. The biochemical properties such as, high processivity, strand-displacement activity and proof-reading activity make PolB and PolD ideally suited for accurate DNA synthesis on recombination intermediates. 
Working with purified $P$. abyssi proteins, here we reconstituted an in vitro assay for recombination-associated DNA synthesis. Based on previous studies with eukaryotic proteins [26,52], we used a purified supercoiled plasmid as the homologous donor substrate and a ssDNA of 93 $\mathrm{nt}$ as the invading strand. In the presence of the RadA recombinase, we managed to produce D-loop substrate and showed that both PolB and PolD can take over RadA-mediated recombination intermediates. Interestingly our results also indicate that PolD is less efficient as compared to PolB to extend the invaded strand in the D-loop substrate. In regards to both biochemical and genetical observations from previous publications, our results support an important role for PolB in HR but also identify PolD as a possible back-up polymerase.

\section{Materials and Methods}

\subsection{Protein Expression and Purification}

\subsection{1. $\operatorname{Rad} A$}

P. abyssi RadA was purified following the protocol published for P. furiosus RadA [10]. The sequence of the gene encoding RadA (Gene ID: 1495130) was optimized for expression in E. coli cells and cloned into pET-30a(+) by Genecust (Ellange, Luxembourg) (optimized sequence in Table S1). RadA was overexpressed in E. coli BL21 (DE3) cells carrying RadA/pET-30a(+). IPTG (isopropyl-1-thio-D-galactopyranoside) was added to a final concentration of $0.1 \mathrm{mM}$, and the cells were further grown for $4 \mathrm{~h}$ at $37^{\circ} \mathrm{C}$ to induce the expression from RadA/pET-30a(+). The cells were harvested by centrifugation at $5000 \times \mathrm{g}$ for $30 \mathrm{~min}$. The cell pellet was resuspended into $50 \mathrm{mM}$ Tris-HCl, pH 8.0, $200 \mathrm{mM} \mathrm{NaCl}, 0.1 \mathrm{mM}$ EDTA, $0.5 \mathrm{mM}$ DTT complemented with protease inhibitors (Roche, \#05056489001, Basel, Switzerland). The cells were disrupted by pressure (One shot, $1.8 \mathrm{kbar}$ ) and sonication then centrifuged at $10,000 \times g$ for $20 \mathrm{~min}$. The supernatant was incubated at $80^{\circ} \mathrm{C}$ for $20 \mathrm{~min}$ and centrifuged again at $10,000 \times g$ for $20 \mathrm{~min}$. Then the soluble fraction was diluted two times with buffer A: $50 \mathrm{mM}$ Tris-HCl, pH 8.0; $0.1 \mathrm{mM}$ EDTA; $0.5 \mathrm{mM}$ DTT; 5\% glycerol to decrease salt concentration before protein precipitation with $0.1 \%$ PEI (Polyethyleneimine), P3143, Sigma, Saint-Louis, MO, USA). The protein sample was incubated for $5 \mathrm{~min}$ on ice and was centrifuged for $10 \mathrm{~min}$ at $3000 \times \mathrm{g}$. The protein pellet was then resuspended with one equal volume of buffer $\mathrm{A}$ complemented with $0.4 \mathrm{M}$ ammonium sulfate and incubated for $15 \mathrm{~min}$ on ice. The soluble fraction was recovered after centrifugation at $3000 \times \mathrm{g}$ for $10 \mathrm{~min}$ and mixed with ammonium sulfate to a final concentration of $2 \mathrm{M}$ before being loaded onto a phenyl-sepharose column (Hiprep phenyl (high sub) FF 16/10, GE Healthcare, Chicago, MI, USA). RadA protein was eluted at $160 \mathrm{mM}$ ammonium sulfate and the fractions were dialyzed against buffer A containing $0.2 \mathrm{M} \mathrm{NaCl}$. The dialysate was applied onto a heparin column (HiTrap heparin, GE Healthcare, Chicago, MI, USA) and eluted at 0.7-1.0 M NaCl. RadA protein was then concentrated with Sartorius Vivaspin (30,000 MWCO, Göttingen, Germany) and applied onto a gel filtration column (Superdex 200, GE Healthcare, Chicago, MI, USA) in the buffer A complemented with $0.2 \mathrm{M} \mathrm{NaCl}$. The final RadA concentration was calculated by measuring absorbance at $280 \mathrm{~nm}$ with a predicted extinction coefficient of $12,950 \mathrm{M}^{-1} \cdot \mathrm{cm}^{-1}$ and molecular weight of 38,760.4 Da (ProtParam, ExPASy, [53]).

\subsubsection{PCNA (Proliferating Cell Nuclear Antigen)}

P. abyssi PCNA (Gene ID: 1496768) was produced and purified as described previously [54]. Briefly, PCNA was overproduced by addition of $1 \mathrm{mM}$ IPTG in E. coli strain BL21-CodonPlus-RIL grown for $4 \mathrm{~h}$ in Lysogeny broth (LB) at $37^{\circ} \mathrm{C}$. The cell extracts were treated by heating at $80{ }^{\circ} \mathrm{C}$ for $10 \mathrm{~min}$, and His-tagged PCNA was purified by using a strong anion exchange column (HiPrep Q FF 16/10, GE Healthcare, Chicago, MI, USA) and an affinity column (HisPrep FF 16/10, GE Healthcare, Chicago, MI, USA). After dialysis and concentration, the final protein sample was stored in $40 \mathrm{mM}$ Tris- $\mathrm{HCl}$, pH 8.0; $0.8 \mathrm{mM}$ DTT; $240 \mathrm{mM} \mathrm{NaCl} ; 0.16 \mathrm{mM}$ EDTA and 20\% glycerol. Protein concentration was 
measured by colorimetric assay based on the Bradford dye-binding method (BioRad protein assay dye reagent, BioRad, Hercules, CA, USA). The recombinant $\mathrm{PaPCNA}$ has a predicted extinction coefficient of $7450 \mathrm{M}^{-1} \cdot \mathrm{cm}^{-1}$ and a molecular weight of 29,433.77 Da (ProtParam, ExPASy, [53]).

\subsubsection{PolB}

exo+ and exo- versions of P. abyssi PolB (Gene ID: GI:1495739) were produced and purified as already described [33].

Briefly, PolB exo+ and exo- were overproduced by addition of $1 \mathrm{mM}$ IPTG in E. coli strain Rosetta 2(DE3)pLysS grown overnight in Lysogeny broth (LB) at $30^{\circ} \mathrm{C}$. The cell extracts were treated by heating for $20 \mathrm{~min}$ at $75^{\circ} \mathrm{C}$, and His-tagged PolB was purified by using an affinity column (HisPrep FF 16/10, GE Healthcare, Chicago, MI, USA) and by hydrophobic chromatography (HiPrep Phenyl (low sub) FF 16/10, GE Healthcare). After dialysis and concentration, the final protein sample was stored in $30 \mathrm{mM}$ Tris- $\mathrm{HCl}, \mathrm{pH} 7.5 ; 0.6 \mathrm{mM} \mathrm{DTT} ; 60 \mathrm{mM} \mathrm{NaCl}$ and $40 \%$ glycerol. Protein concentration was calculated by measuring absorbance at $280 \mathrm{~nm}$. The recombinant $\mathrm{PaPolB}$ has a predicted extinction coefficient of $122,050 \mathrm{M}^{-1} \cdot \mathrm{cm}^{-1}$ and a molecular weight of 89,400.31 Da (ProtParam, ExPASy, [53]).

\subsubsection{PolD}

exo+ and exo- versions of P. abyssi PolD, DP1 (small subunit, Gene ID: 1495007) and DP2 (large subunit, Gene ID: 1495008), were produced and purified as already described [44,55]. Briefly, PolD exo+ and exo- were overproduced by addition of $1 \mathrm{mM}$ IPTG in E. coli strain grown overnight in Lysogeny broth (LB) at $20^{\circ} \mathrm{C}$. The cell extracts were treated by for $30 \mathrm{~min}$ at $70^{\circ} \mathrm{C}$, and his-tagged PolD was purified by using a strong anion exchange column (HiLoad 26/10 Q sepharose, GE Healthcare, Chicago, MI, USA), two affinity columns (HisPrep FF 16/10 and HiTrap Heparin, GE Healthcare, Chicago, MI, USA) and a size exclusion column (Superdex 200, GE Healthcare, Chicago, MI, USA). After concentration, the final protein sample was stored in $35 \mathrm{mM}$ Tris- $\mathrm{HCl}, \mathrm{pH} 7.5 ; 0.7 \mathrm{mM} \beta$-mercaptoethanol; $35 \mathrm{mM}$ $\mathrm{NaCl}$ and $30 \%$ glycerol. Protein concentration was calculated by measuring absorbance at $280 \mathrm{~nm}$. The recombinant $\mathrm{PaPolD}$ exo+ has a predicted extinction coefficient of $63,720 \mathrm{M}^{-1} \cdot \mathrm{cm}^{-1}$ and a molecular weight of 69,395.36 Da for DP1; 152,990 $\mathrm{M}^{-1} \cdot \mathrm{cm}^{-1}$ and 146,368.57 Da for DP2 (ProtParam, ExPASy, [53]). The recombinant $\mathrm{PaPolD}$ exo- has a predicted extinction coefficient of $65,210 \mathrm{M}^{-1} \cdot \mathrm{cm}^{-1}$ and a molecular weight of 74,834.07 Da for DP1; 152,990 $\mathrm{M}^{-1} \cdot \mathrm{cm}^{-1}$ and 144,205.25 Da for DP2 (ProtParam, ExPASy, [53]).

\subsection{DNA Substrates}

\subsubsection{Circular D-Loop}

The L93-5'HL 647 oligonucleotide (5' HiLyte ${ }^{\text {TM }}$ Fluor 647-AAA-GGC-GGT-AAT-ACG-GTT-ATC -CAC-AGA-ATC-AGG-GGA-TAA-CGC-AGG-AAA-GAA-CAT-GTG-AGC-AAA-AGG-CCA-GCA -AAA-GGC-CAG-GAA-CCG-TAA-AAA-3' [26,56] was obtained from Eurogentec (Liege, Belgium). This oligonucleotide is $100 \%$ homologous to pUC19 region 2523-2615. The supercoiled form of pUC19 was purified from E. coli DH5 $\alpha$ transformed with pUC19 plasmid (TAKARA@, Kusatsu, Japan). E. coli cells were grown overnight at $37^{\circ} \mathrm{C}$ in $\mathrm{LB}$ media with $100 \mu \mathrm{g} / \mathrm{mL}$ ampicillin. Then the cells were rapidly cooled in ice before centrifugation at $6000 \times g$ for $15 \mathrm{~min}$. pUC19 plasmid was extracted from the cell pellet by using QIAfilter ${ }^{\mathrm{TM}}$ Plasmid Maxi Kit (Qiagen, Hilden, Germany) according to the manufactural protocol. Then the different form of pUC19 plasmid were separated by electrophoresis on an 1\% TAE agarose gel and visualized by ethidium bromide staining. The supercoiled DNA ladder (N0472S, NEB, Ipswich, MA, USA) was used to identify the supercoiled form of pUC19 (2686 bp) and extracted the corresponding band. The DNA was eluted from the agarose gel using phenol (77607, Sigma, Saint-Louis, MO, USA) then the sample was frozen for $5 \mathrm{~min}$ at $-80^{\circ} \mathrm{C}$ and finally centrifuged at $12,000 \times g$ for $15 \mathrm{~min}$. The plasmid was recovered from the supernatant phase and precipitated with 1:10 volume of $5 \mathrm{M} \mathrm{NaCl}$ and 2.5 volume of cold ethanol and incubated for $15 \mathrm{~min}$ at $-80^{\circ} \mathrm{C}$. After centrifugation for $15 \mathrm{~min}$ at $12,000 \times \mathrm{g}$, the plasmid pellet was washed with $70 \%$ ethanol and centrifuged 
for $5 \mathrm{~min} 12,000 \times \mathrm{g}$. The pellet was dried for $20 \mathrm{~min}$ at room temperature and the purified supercoiled pUC19 was eluted in TE buffer and transfer into a DNA LoBind tube. DNA concentration was calculated from the absorbance at $260 \mathrm{~nm}$ with a DNA calculator tool (from Molbiotools.com, (C) 2019 Vladimír Čermák, Prague, Czech Republic).

\subsubsection{Linear D-Loop}

Synthetic oligonucleotides (sequences are listed in Table S2, [25]) were purchased from Eurogentec (Liege, Belgium). To generate the linear D-loop substrate (S91/29/91), equal molar concentrations of oligonucleotides (Up1_91 nt, Up2_29 nt 5'Fam, Down_91 nt) were mixed in buffer containing $10 \mathrm{mM}$ HEPES, pH 7.5, $100 \mathrm{mM} \mathrm{NaCl}$ and heated at $95^{\circ} \mathrm{C}$ for $5 \mathrm{~min}$, then were gradually cooled down to $20{ }^{\circ} \mathrm{C}$. Then, the substrate was purified from a native acrylamide gel followed by DNA extraction and ethanol precipitation. As control, a primer/template substrate (S29/91, Table S1) was prepared followed by the same annealing protocol without additional purification.

\subsubsection{Linear Primer/Template}

Synthetic oligonucleotides (sequences are listed in Table S3) were purchased from Eurogentec (Liege, Belgium). To generate substrates (S30/87/30), equal molar concentrations of oligonucleotides (Up1_30 nt 5'Cy5, Down_87 nt, Up2_30 nt) were mixed in buffer containing $10 \mathrm{mM} \mathrm{HEPES,} \mathrm{pH} \mathrm{7.5,}$ $100 \mathrm{mM} \mathrm{NaCl}$ and heated at $95^{\circ} \mathrm{C}$ for $5 \mathrm{~min}$, then were gradually cooled down to $20^{\circ} \mathrm{C}$.

\subsection{Enzymatic Assays}

\subsubsection{D-Loop Formation Assays}

An amount of $25 \mathrm{nM} 5^{\prime} \mathrm{HL} 675 \mathrm{~L} 93$ was first incubated with increased quantity of RadA $(0,0.4$, $0.8,1.6,3.2,6.4 \mu \mathrm{M}$ ) for $10 \mathrm{~min}$ at $65^{\circ} \mathrm{C}$ in a buffer containing $20 \mathrm{mM}$ Tris-HCl, pH 8.0, $10 \mathrm{mM}$ DTT, 50 $\mu \mathrm{g} / \mathrm{mL}$ BSA, $10 \mathrm{mM} \mathrm{MgCl}$ and $2.5 \mathrm{mM}$ ATP (when indicated). Then $25 \mathrm{nM}$ of purified supercoiled pUC19 was added and incubated for another $10 \mathrm{~min}$. The final reaction volume was $20 \mu \mathrm{L}$ containing $125 \mathrm{mM} \mathrm{NaCl}$. Reaction was stopped by addition of $5 \mu \mathrm{L}$ of proteinase $\mathrm{K}(250 \mu \mathrm{g} / \mathrm{mL}), 2.5 \%$ SDS, 200 $\mathrm{mM}$ EDTA and incubated at $37^{\circ} \mathrm{C}$ for $15 \mathrm{~min}$. The samples were mixed with equal volume of $20 \%$ Ficoll and subjected to a $1.2 \%$ agarose gel electrophoresis in $1 \times$ TAE buffer. The products were visualized by Typhoon FLA 9500 (GE Healthcare, Chicago, MI, USA) and quantified with ImageQuant software. RadA-dependent D-loop (\%) was calculated with the densitometry measurement of formed D-loop as a percentage of total lane densitometry after data normalization and subtraction of the D-loop background from the control without protein. Experiments were performed in triplicate.

\subsubsection{Circular D-Loop Extension Assays}

$5^{\prime}$ Fam L93 (25 nM) was first incubated with $0.8 \mu \mathrm{M}$ RadA for $10 \mathrm{~min}$ at $65^{\circ} \mathrm{C}$ in a buffer containing $20 \mathrm{mM}$ Tris-HCl, pH 8.0, $10 \mathrm{mM}$ DTT, $50 \mu \mathrm{g} / \mathrm{mL} \mathrm{BSA}, 10 \mathrm{mM} \mathrm{MgCl} 2,0.2 \mathrm{mM}$ dNTPs and $2.5 \mathrm{mM}$ ATP (when indicated). Then, $25 \mathrm{nM}$ of purified pUC19 was added and incubated for another 10 min. Next, the reaction was mixed with DNA polymerases at indicated concentration for a further 60 min. PCNA was added to the reaction mixture when indicated at $675 \mathrm{nM}$. The final reaction volume was $20 \mu \mathrm{L}$, containing $130 \mathrm{mM} \mathrm{NaCl}$. DNA products were separated either by native agarose gel (as described in D-loop formation assays) or by denaturing gels. For denaturing gel electrophoresis, the reactions were terminated by addition of $86 \%$ deionized formamid, $0.01 \mathrm{~N} \mathrm{NaOH}$ and $10 \mathrm{mM}$ EDTA with equal volume. DNA products were analyzed by $5 \%$ denaturing polyacrylamide gel ( $8 \mathrm{M}$ urea) or by $1 \%$ alkaline agarose gel. The electrophoresis images were obtained and the products were quantified as described above. The alkaline agarose gel was stained with SYBR Gold, scanned first to visualize HL-647-labeled products and then scanned for SYBR Gold for detecting the ladder (2-Log DNA ladders, New England Biolabs, Ipswich, MA, USA) and the plasmid pUC19. 


\subsubsection{Linear D-Loop Extension Assays}

5'Fam linear D-loop ( $\mathrm{S}_{91 / 29 / 91}$ or $\left.\mathrm{S}_{29 / 91}\right)$ DNA (25 nM) was incubated with $225 \mathrm{nM}$ DNA PolB or PolD at $65{ }^{\circ} \mathrm{C}$ in a buffer containing $20 \mathrm{mM}$ Tris-HCl, pH 8.0, $10 \mathrm{mM}$ DTT, $50 \mu \mathrm{g} / \mathrm{mL}$ BSA, $10 \mathrm{mM}$ $\mathrm{MgCl}_{2}$ and $0.2 \mathrm{mM}$ dNTPs. PCNA was added to the reaction mixture to $225 \mathrm{nM}$, when indicated. The final reaction volume was $20 \mu \mathrm{L}$, containing $130 \mathrm{mM} \mathrm{NaCl}$. Reactions were terminated by addition of $20 \mu \mathrm{L}$ of $86 \%$ deionized formamid, $0.01 \mathrm{~N} \mathrm{NaOH}, 10 \mathrm{mM}$ EDTA and $1 \mu \mathrm{M}$ reverse complement DNA (Trap_60 nt, Table S1). DNA products were analyzed after separation into an $8 \mathrm{M}$ urea and 15\% denaturing polyacrylamide gel and analyzed as described above.

\subsubsection{Strand Displacement Assays}

$5^{\prime}$ Cy5 linear substrate $\left(\mathrm{S}_{30 / 87 / 30}\right.$ or $\left.\mathrm{S}_{30 / 87}\right)$ DNA $(25 \mathrm{nM})$ was incubated with $225 \mathrm{nM}$ PolB or PolD (exo-) at $65^{\circ} \mathrm{C}$ in a buffer containing $20 \mathrm{mM}$ Tris- $\mathrm{HCl}, \mathrm{pH}$ 8.0, $10 \mathrm{mM}$ DTT, $50 \mu \mathrm{g} / \mathrm{mL}$ BSA, $10 \mathrm{mM}$ $\mathrm{MgCl}_{2}$ and $0.2 \mathrm{mM}$ dNTPs. The final reaction volume was $20 \mu \mathrm{L}$, containing contained $130 \mathrm{mM} \mathrm{NaCl}$. Reactions were terminated by addition of $20 \mu \mathrm{L}$ of $86 \%$ deionized formamid, $0.01 \mathrm{~N} \mathrm{NaOH}, 10 \mathrm{mM}$ EDTA and $1 \mu \mathrm{M}$ reverse complement DNA (Trap_87nt, Table S2). DNA products were analyzed as described above.

\section{Results and Discussion}

During the HR process, the crucial step of DNA synthesis allows faithful recovery of the missing genetic information. Strand invasion by RadA nucleoprotein filament forms a D-loop recombination intermediate that will serve as a primer for a DNA polymerase to initiate DNA synthesis. However, no study about biochemical assays with archaeal DNA polymerases in a DNA recombination context has been reported to date. Here, we reconstituted an in vitro strand synthesis assay system using plasmid-based D-loop substrate. With the aim to study the biochemical properties of archaeal DNA polymerases with or without their accessory proteins on these specific substrates, we combined strand exchange and DNA extension reactions using purified recombinant proteins of P. abyssi (RadA, PolB, PolD, PCNA) (Figure S1).

\subsection{RadA Catalyzes D-Loop Formation on a Circular DNA Substrate}

The RadA recombinase from $P$. abyssi, a member of the RecA family proteins, is a $38.8 \mathrm{kDa}$ protein (Uniprot id: Q9V233). For the archaeal members of this family, in the presence of ATP or ADP, RadA multimerizes and forms a nucleoprotein filament with 3-nucleotides binding for each monomer $[10,19,57]$. After that, the recombinase performs a homology search to find a dsDNA having homologous sequence. The global mechanism is reviewed in [12,56,58]. Briefly, the homology recognition and short strand exchange require binding of ATP, allowing filaments to function as rotary motors. If the bound dsDNA is homologous to the ssDNA, strand exchange is performed through Watson-Crick base pairing and structural transition in the nucleoprotein filament regulates its sensitivity to the homology length [59]. In Bacteria, the physical distance between the two DNA-binding sites of RecA dictates a minimal homologous region of 8 nucleotides (nt) to initiate strand exchange [60]. Then, the nucleoprotein filament is disassembled depending on ATP hydrolysis and may be supported by mediators.

Here we purified the recombinant RadA protein without affinity tag, following a protocol used for $P$. furiosus RadA as described earlier [10,11]. As a control for RadA ssDNA binding activity, we used a fluorescent-labeled ssDNA (93 mer) in electrophoretic mobility shift assays (Figure S2A). As described for $P f \operatorname{RadA}$, here $P a$ RadA bound ssDNA without requiring ATP and within range of protein in agreement with the stoichiometry described above. This ssDNA contained a homologous sequence to a portion of pUC19 plasmid, and was used as the strand to be exchanged by the RadA recombinase. For the plasmid-based D-loop assay, RadA was first incubated with the ssDNA to form the nucleoprotein filament, and then, provided pUC19 (dsDNA with $2686 \mathrm{bp}$ ) to the reaction mixture 
to trigger the homology search (Figure 1A). As mentioned previously by the biochemical studies with eukaryotic proteins $[26,61]$, the purification level of the plasmid used as donor dsDNA is crucial to implement a robust and reproducible result of the in vitro recombination assays. Consequently, we added a final purification step where only the supercoiled form was collected and extracted after separation on gel electrophoresis (see materials and methods section) (Figure S2A). This supercoiled form of pUC19 was used as the DNA template for the recombination assay.

A

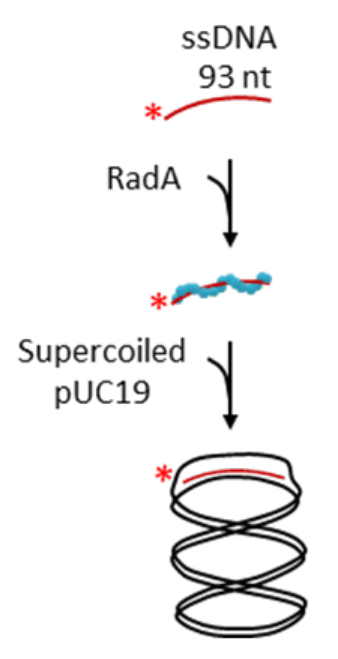

B

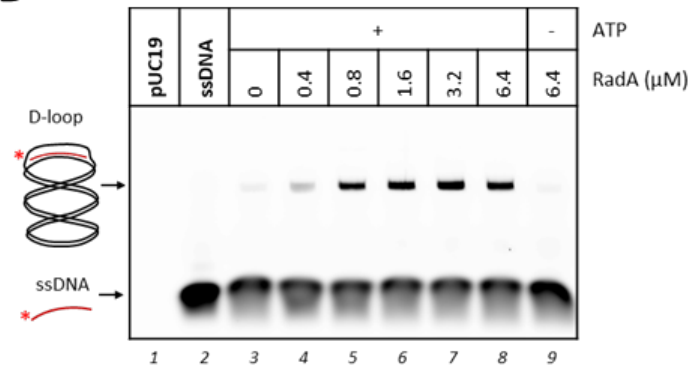

C

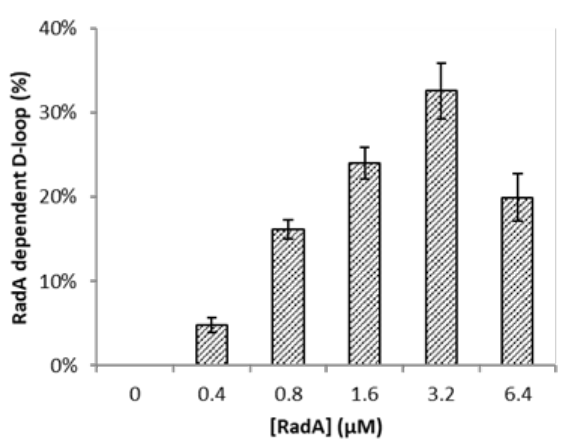

Figure 1. P. abyssi RadA recombinase activity catalyzed displacement-loop (D-loop) formation. (A) Schematic representation for the D-loop formation assay. Labeled linear ssDNA (93 nt) was incubated first with RadA to form nucleoprotein filaments before adding the purified supercoiled plasmid pUC19 for further homology search. (B) D-loop formation assay with increased quantity of RadA. An amount of $25 \mathrm{nM}$ of labeled ssDNA (93 nt) was incubated with RadA for 10 min at 65 ${ }^{\circ} \mathrm{C}$. Then, $25 \mathrm{nM}$ of purified supercoiled pUC19 was added and incubated for another $10 \mathrm{~min}$. DNA products were separated on a $1.2 \%$ native agarose gel and visualized by fluorescence. (C) Histogram representation of the D-loop formation assays for a range of RadA as observed in (B). RadA-dependent D-loop (\%), densitometry measurement of formed D-loop as a percentage of total lane densitometry after data normalization and the D-loop background from lane 3 was subtracted. Experiments were performed in triplicate.

The RadA-mediated nucleofilament formation induced D-loop formation on the pUC19 plasmid as shown in Figure 1B. The upper band with a lower migration velocity, by gel electrophoresis, appeared in the lanes 4 to 8 and should correspond to the ssDNA that invaded the complementary region of pUC19. The staining of the same native gel with SYBR Gold (Figure S2B) confirmed the superposition of the $93 \mathrm{nt}$ ssDNA signal (green) with the plasmid signal (red). This implies that a part of the $93 \mathrm{nt}$ ssDNA invaded into the pUC19 plasmid and hybridized to the homologous region.

These products increased with the concentration of RadA and the reaction is clearly in an ATP-dependent manner (no product in lane 9 without ATP). It is generally known that the binding and hydrolyzing of ATP are required to achieve the strand exchange reaction by the RecA family recombinases, although the DNA binding of the recombinases is not ATP-dependent [11,62]. We noticed a faint band at the same position of the D-loop from the reactions without RadA (lane 3) and without 
ATP (lane 9). These bands are probably derived from the partial annealing of the ssDNA on melted zone of the plasmid, favored by the temperature of the assay at $65^{\circ} \mathrm{C}$.

For the reaction condition of this strand exchange, $0.8 \mu \mathrm{M}$ of RadA is theoretically sufficient to cover $25 \mathrm{nM}$ of the ssDNA with $93 \mathrm{nt}$ from the stoichiometry of 1 monomeric RadA for 3 nucleotides. However, higher yields of D-loop were obtained with higher concentrations of RadA and the D-loop formation reached $33 \%$ as a maximum by $3.2 \mu \mathrm{M}$ of RadA (Figure 1C). The apparently low rate of the strand exchange reaction by the archaeal RadA in vitro was similar to those observed by Rad51 on the same substrate $(\sim 30 \%)$ [26]. Increase in the reaction temperature did not improve the final D-loop yield (Figure S2D).

Some regulators probably exist to enhance the strand exchange activity of RadA. Several RadA paralogs are supposed to regulate RadA activity and may support filament formation on RPA/SSB-coated strand in Archaea [11,14,63-66]. In Sulfolobus solfataricus, a recombinase paralog Ral3 stabilizes the RadA presynaptic filament [64] while Ral1, in conjunction with Ral2, was recently shown to negatively regulate RadA exchange activity [67]. In P. abyssi, only one candidate to be considered from the sequence homology was found. However, any function of this protein, called RadB, has not been identified. In Haloferax volcanii, RadB is supposed to induce conformational change in RadA to promote its polymerization on DNA [68]. In P. furiosus, a direct interaction between RadA and RadB has been detected [11], but functionally the binding of RadB on DNA negatively interfered with the formation of the RadA nucleoprotein filament. Here, in the absence of a stable P. abyssi RadB purified protein, we were not able to test whether RadB would help RadA in the D-loop formation assay.

Biochemical studies with eukaryotic proteins demonstrated that the ssDNA binding protein RPA, if added to the partially formed nucleoprotein filament, promotes the fully assembled Rad51 filament (reviewed in $[56,69]$ ). When added before Rad51, RPA binding affinity to ssDNA usually inhibits filament formation of Rad51 and Rad52 is required as a mediator on this RPA-coated ssDNA. During our experiments we also added P. abyssi RPA at different steps of the nucleoprotein filament formation reaction, but RPA always reduced D-loop formation in all conditions (data not shown). Taken together, the archaeal RadA recombinase probably acts in coordination with modulators that remain to be identified and characterized to catalyze efficient nucleofilament formation and strand exchange in vivo.

For the reconstitution of recombination-associated DNA Synthesis with eukaryotic proteins, it was reported that $30 \%$ of D-loop formation was sufficient to characterize the following step of DNA synthesis [26]. As we produced a similar amount of D-loop substrate (33\%) in our archaeal in vitro system, we next sought to examine the DNA synthesis activity of the archaeal DNA polymerases on this substrate.

\subsection{P. abyssi DNA Polymerases Extend RadA-Dependent D-Loops}

D-loop formation provides a primer with a $3^{\prime}$ end available for further $5^{\prime}$ to $3^{\prime}$ DNA synthesis by DNA polymerases. In the next experiments we sought to find out which of the two DNA polymerases from P. abyssi, PolB and PolD, could use this substrate for DNA synthesis. We added PolB or PolD to the solution after RadA-mediated D-loop formation and incubated for further $60 \mathrm{~min}$ at $65^{\circ} \mathrm{C}$ as described in Figure 2A. We used DNA polymerases with mutations to disrupt $3^{\prime}-5^{\prime}$ exonuclease activity for this study just to simplify data analysis. Preliminary experiments with various concentrations of DNA polymerases were performed and selected $675 \mathrm{nM}$ for further analysis (Figure S3). As shown in Figure 2B, addition of DNA polymerases led to accumulation of new DNA products with slower migration rate than the initial D-loop (compare lane 4 with lanes 5-6 and 8-9). These bands appeared only in presence of RadA, ATP and DNA polymerases. It was clear that the D-loop signal decreased (from $14 \%$ to $3 \%$ ) balanced with increasing of the lower migrated signals especially in presence of PolB (from $0 \%$ to $30 \%$ ), suggesting that the reaction products correspond to the signals of extended D-loop (Figure S3B). 
A

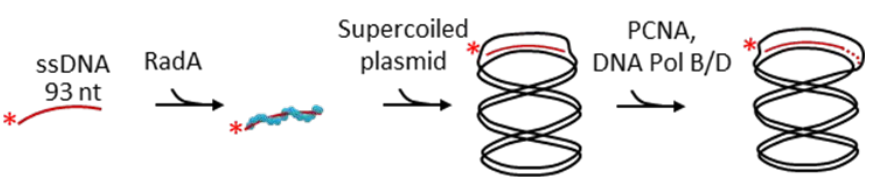

B
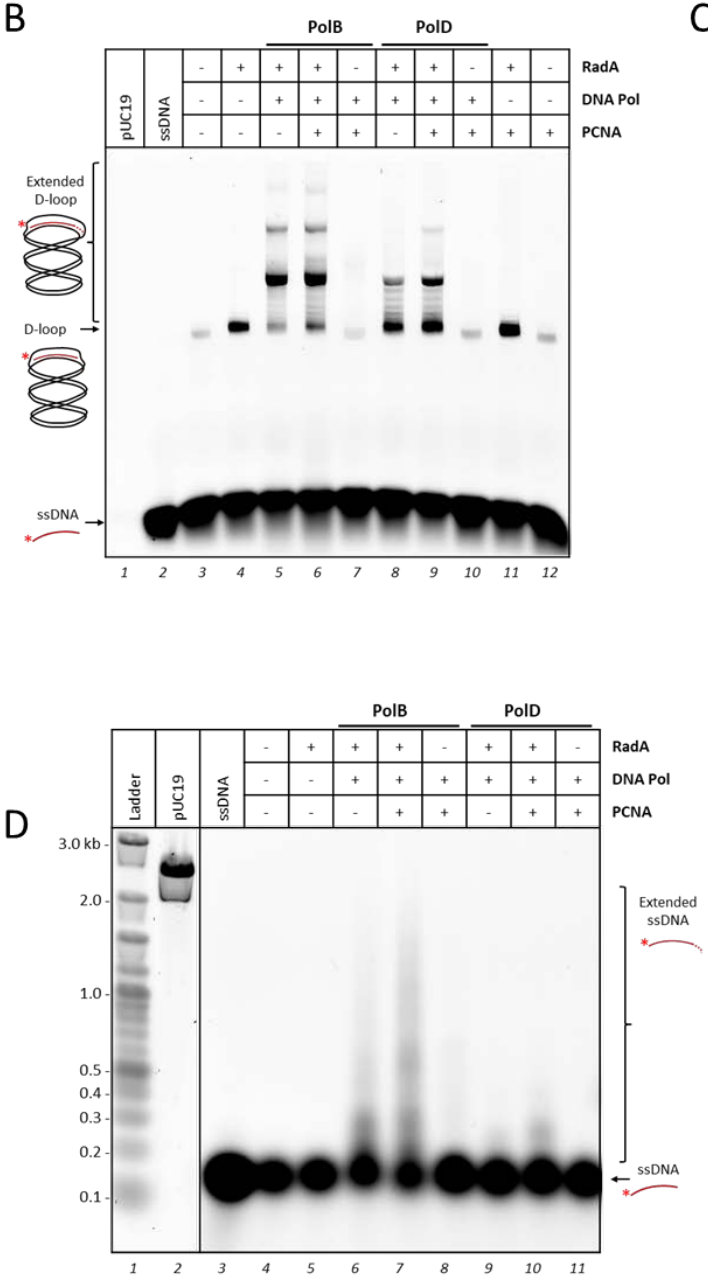

C

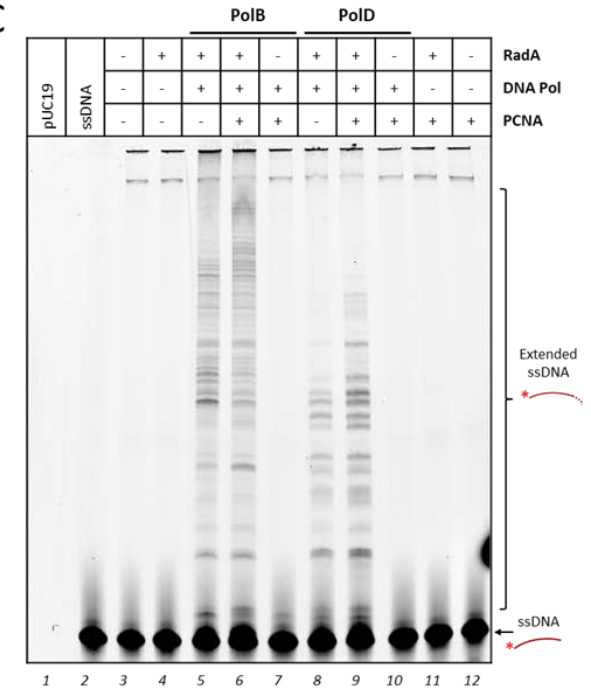

Figure 2. Addition of PCNA stimulates DNA extension by DNA polymerases on recombination intermediates. (A) Schematic representation for DNA extension by family-B polymerase (PolB) or family-D polymerase (PolD) following the D-loop formation by RadA described in Figure 1A. (B) Recombination-associated DNA synthesis assay. An amount of $25 \mathrm{nM}$ of labeled ssDNA was first incubated with $1.6 \mu \mathrm{M}$ RadA for $10 \mathrm{~min}$ at $65^{\circ} \mathrm{C}$. Then, $25 \mathrm{nM}$ of purified supercoiled pUC19 was added and incubated for another $10 \mathrm{~min}$. D-loop provided by RadA strand exchange activity was extended by $675 \mathrm{nM}$ of PolB or PolD for $1 \mathrm{hr}$ at $65^{\circ} \mathrm{C}$. DNA products were separated on a $1.2 \%$ native agarose gel. Same DNA products from (B) were separated as well in 5\% denaturing acrylamide gel (C) or 1\% denaturing alkaline agarose gel (D). When indicated, $675 \mathrm{nM}$ of PCNA was added together with DNA polymerases. DNA products were revealed by fluorescence for HiLyte ${ }^{\mathrm{TM}} 647$ labeled DNA. The denaturing alkaline agarose gel (D) was also stained by SYBR Gold to detect the DNA ladder (lane 1) and pUC19 plasmid (lane 2). For all the experiments, controls were treated as the assays (volume and incubation time), when a protein was absent it was replaced by the corresponding buffer. The two bands at the top of the gel in lanes 3 to 12 are non-specific products corresponding to incomplete denaturation of pUC19 plasmid with residual labelled ssDNA fixed on melted regions.

To further analyze the reaction products by DNA polymerases, the same reaction mixtures were separated on denaturing acrylamide gel. The Figure 2C shows DNA strands extended from the ssDNA 
that invaded into pUC19 with various lengths. The extended products were detected as some discrete sizes in Figure 2B, but they were separated to various sizes by the denaturing condition in Figure 2C.

Next, we evaluated whether PCNA, which interacts and confers processivity to PolB and PolD [32], would improve the extension reaction in the D-loop. We reported the direct interaction between PCNA and Mre11/Rad50, a sensor of DSBs previously [70], suggesting that PCNA is present on DNA during the resection process, the early step of DSB repair in P. abyssi. Therefore, PCNA is suspected to be on DNA for DNA synthesis during HR. As shown in Figure 2C, addition of PCNA increased the length of the extended product by both PolB and PolD as compared with the reactions by each DNA polymerase by itself. The alkaline denaturing agarose gel electrophoresis showed the difference of the product length more clearly (Figure 2D).

To confirm that the wild type PolB and D, named exo+, was also capable of robust D-loop extension, the same reactions were performed with exo+ enzymes (Figure S4). The similar images with slightly shorter sizes were obtained from the extension reaction from the D-loop structure, although some degradation products by the exonuclease activities were observed on free labeled-ssDNA (Figure S4B).

PolB synthesized a longer product from the D-loop structure than PolD, but the sizes still did not reach the full-length of the plasmid template (Figure 2D, compare lane 2 to lane 7). These results suggest that DNA synthesis initiated at the D-loop is limited either by topological constraint or/and by additional partner missing.

In our recombination-associated DNA synthesis assay, extension of the 3 'end could induce torsional strain in the closed circular template DNA depending on how D-loop extension proceeds [24]. In the expanding D-loop model, the D-loop size would grow along with DNA synthesis leading to the accumulation of topological constraints beyond the DNA polymerase. While in the migrating D-loop model, the D-loop bubble would stay with a constant size thanks to the release of the invading strand from the $5^{\prime}$ end [71].

In our assays, we observed in the native gel (Figure 2B), evenly spaced migrating species as well as majority of products (pointed out with arrows) both in the presence of PolB and PolD. These profiles are similar to those observed in the recombination-associated DNA synthesis assay using eukaryotic proteins with the same primer/pUC19 plasmid as ours [26]. In the eukaryotic study, they combined native with denaturing two-dimensional gel electrophoresis and demonstrated first that these evenly spaced migrating species likely corresponded to distinct topoisomers of extended-relaxed D-loops. In addition, they showed that this pattern displayed stall regions relevant to a mechanism whereby the D-loop size is directly correlated to the length of DNA synthesis, resulting in an expanding D-loop until DNA synthesis stalling. In their assays, the initial stall region was relieved after addition of the Topoisomerase I which suppressed topological constraints. However, no significant difference was observed in distribution of the product length, suggesting that the DNA synthesis process would follow a migration D-loop model for longer DNA products (>200 nt). We obtained the similar migration profiles of extended D-loops by the P. abyssi DNA polymerases, and therefore, suggest that Archaea has a similar mechanism to extend DNA strand in the D-loop structures. Additional experiments with topoisomerases would be required to confirm the hypothesis and get a better understanding of the mechanism in the archaeal cells.

To summarize, on these assays we reconstituted an in vitro system showing that RadA provided a D-loop substrate usable for further DNA extension by both archaeal DNA polymerases, PolB and PolD. PCNA supported DNA polymerase activity as the processive factor to go further in extending DNA. However, PolD was less efficient to extend DNA at the D-loop as compared with PolB. PolB managed to extend $88 \%$ of total ssDNA primer engaged in D-loops compared to $46 \%$ for PolD (Figure $2 \mathrm{~B}$, compare lanes 5 and 8). This significant difference was also noticed with PolD exo+ (Figure S4A). To try to better understand this functional difference, we next compared PolB and PolD activities on simpler D-loop substrates. 


\subsection{PolD is Less Efficient Compare to PolB to Extend D-loop Like Substrate}

We made a D-loop substrate by in vitro recombinase activity of RadA, and therefore, we could not thus conclude if the presence of RadA onto DNA would not affect the DNA synthesis activities of PolB and PolD. One report showed that the RecA nucleoprotein filament was required for activation of the Pol V-catalyzed TLS in Bacteria [72]. No study has been reported showing physical or functional interaction of the RadA recombinase with either PolB or PolD to date. In our hands, any of the purified P. abyssi RadA, PolB, and PolD were not co-immunoprecipitated (data not shown).

To examine DNA polymerase activity on recombination intermediate in absence of RadA, we used a synthetic linear D-loop substrate as a model substrate for the following DNA synthesis. The synthetic D-loop contains a $5^{\prime}$ fluorescent 29-nucleotide primer that can be extended by strand displacement of the 30-base pair duplex to form a 60-nucleotide-long product. The polymerase can extend the primer by $1 \mathrm{nt}$ before encountering the dsDNA region of the D-Loop substrate (Figure 3A).

A

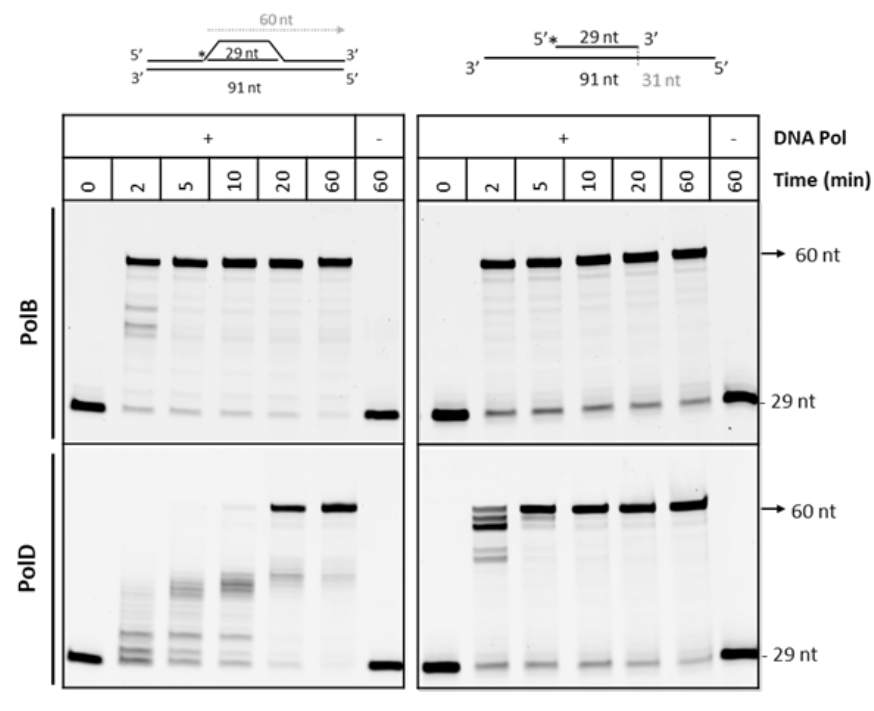

B

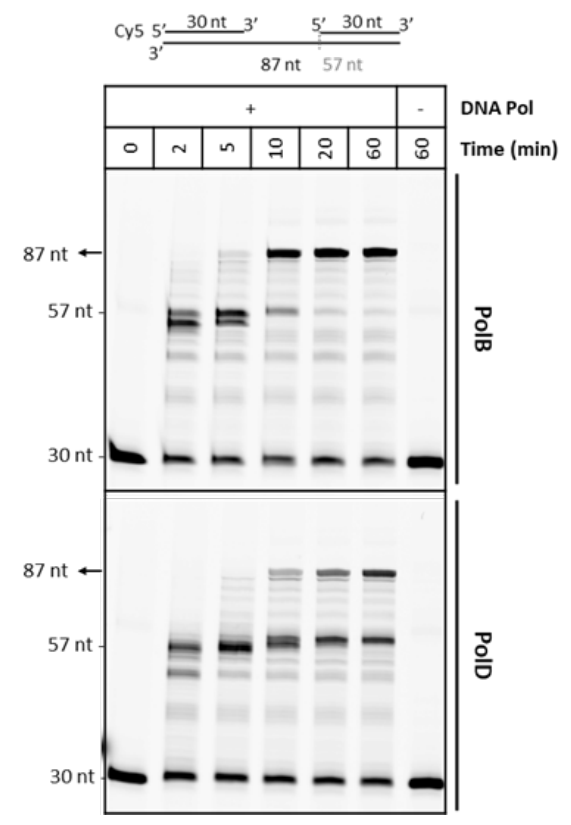

Figure 3. DNA synthesis activity of PolB and PolD on linear substrates. (A) Kinetics of reaction for extension of the 5' end labeled $29 \mathrm{nt}$ for the linear D-loop S91/29/30 or primer/template S29/91. (B) Strand displacement activity of DNA polymerases. A quantity of $225 \mathrm{nM}$ of PolB or PolD was incubated with $25 \mathrm{nM}$ synthetic linear DNA substrates at $65^{\circ} \mathrm{C}$ for a range of time indicated. DNA products were separated by gel electrophoresis onto a $15 \%$ denaturing acrylamide gel and revealed by fluorescence.

We first tested different concentrations of PolB and PolD in a standard experiment, and selected the concentration of $225 \mathrm{nM}$ for further kinetic analysis; both polymerases behaved similarly in synthesizing the full-length product (Figure S5). Then, we compared the DNA synthesis of PolB and PolD on two DNA substrates, the linear D-loop and a simple primed substrate (Figure 3A). We found a clear delay of extension by PolD as compared with PolB to fully extend from the D-loop (Figure 3A, left panel). Similar delay was observed when comparing PolD exo+ and PolB exo+ (data not shown). It was not clear if the difference of efficiency between PolB and PolD was related to primer recognition or strand displacement activity.

To examine the strand-displacement activity in our reaction conditions, we used another synthetic substrate, in which a $5^{\prime}$ labeled $30 \mathrm{nt}$ is annealed to one extremity of the $87 \mathrm{nt}$ template, whereas another $30 \mathrm{nt}$ oligonucleotide is hybridized at the other end resulting in a $27 \mathrm{nt}$ ssDNA gap, as illustrated in Figure 3B. As this substrate was not purified, an excess of the labeled primer may appear and remained 
after extension reaction. The reaction products using this substrate were analyzed by a denaturing gel, and found that PolB and PolD were able to fully extend the primer to the end of the template DNA (87 mer) with a stall at $57 \mathrm{nt}$ corresponding to the ss/dsDNA junction, indicating that PolB and PolD have shome DNA strand displacement activity. However, it was clear that PolD extended less efficiently than PolB after reaching the ss/dsDNA junction.

For primer recognition, a gel retardation assay was performed to compare the binding affinities of PolB and PolD to the D-loop substrate. However, this experiment did not allow us to determine if PolD has a reduced affinity for D-loop substrate as compared to PolB (data not shown). Another possibility is that access of PolD to the primed substrate might be limited before displacing DNA strand, because the space around the $3^{\prime}$-terminus of the primer in this substrate is not wide enough for PolD, which is a complex of $215 \mathrm{kDa}$ with a predicted $\mathrm{Rg}$ of $39.1 \AA$ (calculated from the structure $6 \mathrm{~T} 8 \mathrm{H}$, [73]) (Figure S6). In comparison, PolB, a relatively small molecule with a molecular weight of $89 \mathrm{kDa}$ and a predicted $\operatorname{Rg}$ of $28.5 \AA$ (calculated from the structure 4FLU, [33]), is easy to access to the primer region. On the D-loop substrate, the access to 3' end of the primer should be harder by DNA topology constraint especially in the context of a supercoiled DNA template. We can reasonably suspect that protein partners such as a topoisomerase or even a DNA helicase could be recruited during the process to facilitate DNA polymerase work. Nevertheless, our current in vitro study demonstrates a consistent result that PolB seems to be more suitable DNA polymerase to work on a D-loop substrate.

\section{Conclusions}

In conclusion, we reconstituted an in vitro system for recombination-associated DNA synthesis process with the recombinant proteins of the hyperthermophilic archaeon, P. abyssi: RadA, PCNA, PolB, PolD. Based on our results, we propose that both DNA polymerases can interact and extend the recombination intermediate provided by RadA. In addition, PCNA loading stimulated DNA polymerases to displace the DNA strand and thus further extend the primer. Nevertheless, we suspect that the difference in strand displacement ability accounts for the difference in efficiency for the extension of D-loop substrate and that structure of PolD could also be disadvantage to get access to D-loop primer. This last observation could be consistent with previous genetic studies. Gene deletion studies in Thermococcus kodakarensis, and Methanococcus maripaludis showed that only PolD was essential for cell survival and may be the only replicative DNA polymerase required to replicate both the leading and lagging strand [50,51]. Interestingly the recent study demonstrated that a strain deleted of PolB has higher sensitivity to DNA-damaging agents such as gamma-ray irradiation, main source of double-strand breaks [49]. Together with these data, we propose that PolB could be a good candidate for DNA synthesis during HR process in our archaeal model, and that PolD could take over if required.

These data are noteworthy in respect to the potential role of HR proteins in the replication initiation. In the process named Recombination-Dependent Replication (RDR), the replication machinery is assembled onto D-loop recombination intermediates and the invaded $3^{\prime} \mathrm{DNA}$ end is used as primer for leading strand synthesis (reviewed in [74]). As already mentioned in the introduction, genetic studies in Archaea showed that oriCs were not always essential for growth and were not always systematically activated [8,9]. Interestingly in these studies, the oriC-independent replications are related to the HR process.

In the RDR process, beyond the repair of a DNA strand, full genetic information has to be replicated. As shown in our present study, archaeal PolB and PolD, associated with PCNA, have the capability to extend the primer provided during the strand exchange by RadA. Biochemically, it would be interesting to further analyze the archaeal replisome machinery assembling onto a D-loop substrate. PolD, as an essential DNA polymerase in several Thermococcales species, would have a major role in such a context. However, we could imagine a potential cooperation with PolB which has been shown to be the more suitable for HR process. Currently, T. barophilus would be a model organism for genetic studies. The polB deletion mutant has been isolated and isolation of the $c d c 6$ 
deletion mutant is now underway. These materials would be useful for further understanding of interaction between recombination and replication processes in Archaea.

Supplementary Materials: The following are available online at www.mdpi.com/xxx/s1, Figure S1: Electrophoretic profile of purified P. abyssi proteins, Figure S2: RadA DNA binding and strand invasion activities, Figure S3: D-loop extension assays, Figure S4. D-loop formation and extension assays with Pol B and Pol D exo+. Figure S5. DNA synthesis activity on linear D-loop substrate with increased concentrations of Pol B and Pol D, Figure S6. P. abyssi DNA polymerase structures, Table S1. P. abyssi radA DNA sequence optimized for E. coli expression, Table S2. Sequences of synthetic oligonucleotides used for linear D-loop extension assays, Table S3. Sequences of synthetic oligonucleotides used for strand displacement assays.

Author Contributions: Conceptualization, G.H., Y.L. and D.F.; Funding acquisition, D.F.; Investigation, G.H., Y.L., N.A., A.B. and R.D.; Methodology, G.H., Y.L. and N.A.; Resources, A.B.; Supervision, G.H., Y.L. and D.F.; Validation, G.H. and Y.L.; Visualization, G.H. and D.F.; Writing—original draft, G.H.; Writing—review \& editing, G.H., Y.L., R.D., S.I., Y.I. and D.F. All authors have read and agreed to the published version of the manuscript.

Funding: This work was supported by Ifremer, University of Western Brittany and the LIA1211 MICROBSEA for funding.

Acknowledgments: G.H. would like to thank Damien Huberdeau and Marie Monfort for their initial work regarding the purification and activity analysis of Pyrococcus abyssi RadA. G.H. and D.F. are grateful to Ghislaine Henneke for the helpful discussions and precious advice about archaeal DNA polymerases.

Conflicts of Interest: The authors declare no conflict of interest.

\section{References}

1. Wright, W.D.; Shah, S.S.; Heyer, W.-D. Homologous recombination and the repair of DNA double-strand breaks. J. Biol. Chem. 2018, 293, 10524-10535. [CrossRef] [PubMed]

2. Pannunzio, N.R.; Watanabe, G.; Lieber, M.R. Nonhomologous DNA end-joining for repair of DNA double-strand breaks. J. Biol. Chem. 2017, 293, 10512-10523. [CrossRef] [PubMed]

3. Sallmyr, A.; Tomkinson, A.E. Repair of DNA double-strand breaks by mammalian alternative end-joining pathways. J. Biol. Chem. 2018, 293, 10536-10546. [CrossRef] [PubMed]

4. White, M.F.; Allers, T. DNA repair in the archaea-An emerging picture. FEMS Microbiol. Rev. 2018, 42, 514-526. [CrossRef]

5. Fujikane, R.; Ishino, S.; Ishino, Y.; Forterre, P. Genetic analysis of DNA repair in the hyperthermophilic archaeon, Thermococcus kodakaraensis. Genes Genet. Syst. 2010, 85, 243-257. [CrossRef]

6. Zhang, C.; Tian, B.; Li, S.; Ao, X.; Dalgaard, K.; Gokce, S.; Liang, Y.; She, Q. Genetic manipulation in Sulfolobus islandicus and functional analysis of DNA repair genes. Biochem. Soc. Trans. 2013, 41, 405-410. [CrossRef]

7. Huang, Q.; Liu, L.; Liu, J.; Ni, J.; She, Q.; Shen, Y. Efficient $5^{\prime}-3^{\prime}$ DNA end resection by HerA and NurA is essential for cell viability in the crenarchaeon Sulfolobus islandicus. BMC Mol. Biol. 2015, 16, 2. [CrossRef]

8. Hawkins, M.; Malla, S.; Blythe, M.J.; Nieduszynski, C.A.; Allers, T. Accelerated growth in the absence of DNA replication origins. Nature 2013, 503, 544-547. [CrossRef]

9. Gehring, A.M.; Astling, D.P.; Matsumi, R.; Burkhart, B.W.; Kelman, Z.; Reeve, J.N.; Jones, K.L.; Santangelo, T.J. Genome Replication in Thermococcus kodakarensis Independent of Cdc6 and an Origin of Replication. Front. Microbiol. 2017, 8, 2084. [CrossRef]

10. Komori, K.; Miyata, T.; Daiyasu, H.; Toh, H.; Shinagawa, H.; And, Y.I. Domain Analysis of an Archaeal RadA Protein for the Strand Exchange Activity. J. Biol. Chem. 2000, 275, 33791-33797. [CrossRef]

11. Komori, K.; Miyata, T.; DiRuggiero, J.; Holley-Shanks, R.; Hayashi, I.; Cann, I.K.O.; Mayanagi, K.; Shinagawa, H.; Ishino, Y. Both RadA and RadB are involved in homologous recombination inPyrococcus furiosus. J. Biol. Chem. 2000, 275, 33782-33790. [CrossRef] [PubMed]

12. Renkawitz, J.; Lademann, C.A.; Jentsch, S. Mechanisms and principles of homology search during recombination. Nat. Rev. Mol. Cell Biol. 2014, 15, 369-383. [CrossRef] [PubMed]

13. Chang, Y.-W.; Ko, T.-P.; Lee, C.-D.; Chang, Y.-C.; Lin, K.-A.; Chang, C.-S.; Wang, A.H.-J.; Wang, T.-F. Three new structures of left-handed RadA helical filaments: Structural flexibility of N-Terminal domain is critical for recombinase activity. PLoS ONE 2009, 4, e4890. [CrossRef] [PubMed] 
14. McRobbie, A.-M.; Carter, L.G.; Kerou, M.; Liu, H.; McMahon, S.A.; Johnson, K.A.; Oke, M.; Naismith, J.H.; White, M.F. Structural and Functional Characterisation of a Conserved Archaeal RadA Paralog with Antirecombinase Activity. J. Mol. Boil. 2009, 389, 661-673. [CrossRef]

15. Lee, M.; Lipfert, J.; Sánchez, H.; Wyman, C.; Dekker, N.H. Structural and torsional properties of the RAD51-dsDNA nucleoprotein filament. Nucleic Acids Res. 2013, 41, 7023-7230. [CrossRef]

16. Short, J.M.; Liu, Y.; Chen, S.; Soni, N.; Madhusudhan, M.S.; Shivji, M.K.; Venkitaraman, A.R. High-resolution structure of the presynaptic RAD51 filament on single-stranded DNA by electron cryo-microscopy. Nucleic Acids Res. 2016, 44, 9017-9030. [CrossRef]

17. Xu, J.; Zhao, L.; Xu, Y.; Zhao, W.; Sung, P.; Wang, H.-W. Cryo-EM structures of human RAD51 recombinase filaments during catalysis of DNA-strand exchange. Nat. Struct. Mol. Biol. 2016, 24, 40-46. [CrossRef]

18. Brouwer, I.; Moschetti, T.; Candelli, A.; Garcin, E.B.; Modesti, M.; Pellegrini, L.; Wuite, G.J.L.; Peterman, E.J.G. Two distinct conformational states define the interaction of human RAD 51-ATP with single-stranded DNA. EMBO J. 2018, 37, e98162. [CrossRef]

19. Shin, D.S.; Pellegrini, L.; Daniels, D.; Yelent, B.; Craig, L.; Bates, D.; Yu, D.S.; Shivji, M.K.; Hitomi, C.; Arvai, A.S.; et al. Full-length archaeal Rad51 structure and mutants: Mechanisms for RAD51 assembly and control by BRCA2. EMBO J. 2003, 22, 4566-4576. [CrossRef]

20. Pomerantz, R.T.; Goodman, M.F.; O’Donnell, M. DNA polymerases are error-prone at RecA-mediated recombination intermediates. Cell Cycle 2013, 12, 2558-2563. [CrossRef]

21. Pomerantz, R.T.; Kurth, I.; Goodman, M.F.; E O'Donnell, M.; O’Donnell, M. Preferential D-loop extension by a translesion DNA polymerase underlies error-prone recombination. Nat. Struct. Mol. Biol. 2013, 20, 748-755. [CrossRef]

22. Xu, L.; Marians, K.J. A Dynamic RecA Filament Permits DNA Polymerase-catalyzed Extension of the Invading Strand in Recombination Intermediates. J. Biol. Chem. 2002, 277, 14321-14328. [CrossRef]

23. McIlwraith, M.; Vaisman, A.; Liu, Y.; Fanning, E.; Woodgate, R.; West, S. Human DNA Polymerase $\eta$ Promotes DNA Synthesis from Strand Invasion Intermediates of Homologous Recombination. Mol. Cell 2005, 20, 783-792. [CrossRef] [PubMed]

24. Li, X.; Stith, C.M.; Burgers, P.M.; Heyer, W.-D. PCNA Is Required for Initiation of Recombination-Associated DNA Synthesis by DNA Polymerase $\delta$. Mol. Cell 2009, 36, 704-713. [CrossRef]

25. Li, J.; Holzschu, D.L.; Sugiyama, T. PCNA is efficiently loaded on the DNA recombination intermediate to modulate polymerase $\delta, \eta$, and $\zeta$ activities. Proc. Natl. Acad. Sci. USA 2013, 110, 7672-7677. [CrossRef] [PubMed]

26. Sneeden, J.L.; Grossi, S.M.; Tappin, I.; Hurwitz, J.; Heyer, W.-D. Reconstitution of recombination-associated DNA synthesis with human proteins. Nucleic Acids Res. 2013, 41, 4913-4925. [CrossRef] [PubMed]

27. Kolinjivadi, A.M.; Sannino, V.; De Antoni, A.; Zadorozhny, K.; Kilkenny, M.; Técher, H.; Baldi, G.; Shen, R.; Ciccia, A.; Pellegrini, L.; et al. Smarcal1-mediated fork reversal triggers Mre11-dependent degradation of nascent DNA in the absence of Brca2 and stable Rad51 Nucleofilaments. Mol. Cell 2017, 67, 867-881.e7. [CrossRef]

28. Wang, X.; Ira, G.; Tercero, J.A.; Holmes, A.M.; Diffley, J.F.X.; Haber, J.E. Role of DNA Replication Proteins in Double-Strand Break-Induced Recombination in Saccharomyces cerevisiae. Mol. Cell. Biol. 2004, 24, 6891-6899. [CrossRef] [PubMed]

29. Ganai, R.A.; Zhang, X.-P.; Heyer, W.-D.; Johansson, E. Strand displacement synthesis by yeast DNA polymerase $\varepsilon$. Nucleic Acids Res. 2016, 44, 8229-8240. [CrossRef] [PubMed]

30. Raia, P.; Delarue, M.; Sauguet, L. An updated structural classification of replicative DNA polymerases. Biochem. Soc. Trans. 2019, 47, 239-249. [CrossRef] [PubMed]

31. Cooper, C.D. Archaeal DNA polymerases: New frontiers in DNA replication and repair. Emerg. Top. Life Sci. 2018, 2, 503-516. [CrossRef]

32. Cann, I.K.O.; Ishino, S.; Hayashi, I.; Komori, K.; Toh, H.; Morikawa, K.; Ishino, Y. Functional Interactions of a Homolog of Proliferating Cell Nuclear Antigen with DNA Polymerases inArchaea. J. Bacteriol. 1999, 181, 6591-6599. [CrossRef]

33. Gouge, J.; Ralec, C.; Henneke, G.; Delarue, M. molecular recognition of canonical and deaminated bases by P. abyssi family B DNA Polymerase. J. Mol. Biol. 2012, 423, 315-336. [CrossRef] [PubMed]

34. Uemori, T.; Sato, Y.; Kato, I.; Doi, H.; Ishino, Y. A novel DNA polymerase in the hyperthermophilic archaeon, Pyrococcus furiosus: Gene cloning, expression, and characterization. Genes Cells 1997, 2, 499-512. [CrossRef] 
35. Raia, P.; Carroni, M.; Henry, E.; Pehau-Arnaudet, G.; Brûlé, S.; Béguin, P.; Henneke, G.; Lindahl, E.; Delarue, M.; Sauguet, L. Structure of the DP1-DP2 PolD complex bound with DNA and its implications for the evolutionary history of DNA and RNA polymerases. PLoS Biol. 2019, 17, e3000122. [CrossRef] [PubMed]

36. Boudsocq, F. Sulfolobus solfataricus P2 DNA polymerase IV (Dpo4): An archaeal DinB-like DNA polymerase with lesion-bypass properties akin to eukaryotic poleta. Nucleic Acids Res. 2001, 29, 4607-4616. [CrossRef]

37. Le Breton, M.; Henneke, G.; Norais, C.; Flament, D.; Myllykallio, H.; Querellou, J.; Raffin, J.-P. The Heterodimeric Primase from the Euryarchaeon Pyrococcus abyssi: A Multifunctional Enzyme for Initiation and Repair? J. Mol. Biol. 2007, 374, 1172-1185. [CrossRef]

38. Jozwiakowski, S.K.; Keith, B.J.; Gilroy, L.; Doherty, A.J.; Connolly, B.A. An archaeal family-B DNA polymerase variant able to replicate past DNA damage: Occurrence of replicative and translesion synthesis polymerases within the B family. Nucleic Acids Res. 2014, 42, 9949-9963. [CrossRef]

39. Lemor, M.; Kong, Z.; Henry, E.; Brizard, R.; Laurent, S.; Bossé, A.; Henneke, G. Differential activities of DNA Polymerases in processing Ribonucleotides during DNA synthesis in Archaea. J. Mol. Biol. 2018, 430, 4908-4924. [CrossRef]

40. Killelea, T.; Palud, A.; Akcha, F.; Lemor, M.; L'Haridon, S.; Godfroy, A.; Henneke, G. The interplay at the replisome mitigates the impact of oxidative damage on the genetic integrity of hyperthermophilic Archaea. Elife 2019, 8, e45320. [CrossRef]

41. Gueguen, Y.; Rolland, J.-L.; Lecompte, O.; Azam, P.; Le Romancer, G.; Flament, D.; Raffin, J.-P.; Dietrich, J. Characterization of two DNA polymerases from the hyperthermophilic euryarchaeonPyrococcus abyssi. Eur. J. Biochem. 2001, 268, 5961-5969. [CrossRef] [PubMed]

42. Rouillon, C.; Henneke, G.; Flament, D.; Querellou, J.; Raffin, J.-P. DNA polymerase switching on Homotrimeric PCNA at the replication fork of the Euryarchaea Pyrococcus abyssi. J. Mol. Biol. 2007, 369, 343-355. [CrossRef] [PubMed]

43. Henneke, G.; Flament, D.; Hübscher, U.; Querellou, J.; Raffin, J.-P. The Hyperthermophilic Euryarchaeota Pyrococcus abyssi Likely Requires the Two DNA Polymerases D and B for DNA Replication. J. Mol. Biol. 2005, 350, 53-64. [CrossRef] [PubMed]

44. Palud, A.; Villani, G.; L'Haridon, S.; Querellou, J.; Henneke, G.; Raffin, J.-P. Intrinsic properties of the two replicative DNA polymerases ofPyrococcus abyssiin replicating abasic sites: Possible role in DNA damage tolerance? Mol. Microbiol. 2008, 70, 746-761. [CrossRef]

45. Ralec, C.; Henry, E.; Lemor, M.; Killelea, T.; Henneke, G. Calcium-driven DNA synthesis by a high-fidelity DNA polymerase. Nucleic Acids Res. 2017, 45, 12425-12440. [CrossRef]

46. Greenough, L.; Kelman, Z.; Gardner, A.F. The roles of family B and D DNA polymerases in Thermococcus species $9^{\circ} \mathrm{N}$ Okazaki fragment maturation. J. Biol. Chem. 2015, 290, 12514-12522. [CrossRef]

47. Henneke, G. In vitro reconstitution of RNA primer removal in Archaea reveals the existence of two pathways. Biochem. J. 2012, 447, 271-280. [CrossRef]

48. Ishino, S.; Ishino, Y. Comprehensive Search for DNA Polymerase in the Hyperthermophilic Archaeon, Pyrococcus furiosus. Nucleosides Nucleotides Nucleic Acids 2006, 25, 681-691. [CrossRef]

49. Kushida, T.; Narumi, I.; Ishino, S.; Ishino, Y.; Fujiwara, S.; Imanaka, T.; Higashibata, H. PolB, a Family B DNA Polymerase, in Thermococcus kodakarensis is Important for DNA Repair, but not DNA Replication. Microbes Environ. 2019, 34, 316-326. [CrossRef]

50. Sarmiento, F.; Mrázek, J.; Whitman, W.B. Genome-scale analysis of gene function in the hydrogenotrophic methanogenic archaeon Methanococcus maripaludis. Proc. Natl. Acad. Sci. USA 2013, 110, 4726-4731. [CrossRef]

51. Čuboňová, L.; Richardson, T.; Burkhart, B.W.; Kelman, Z.; Connolly, B.A.; Reeve, J.N.; Santangelo, T.J. Archaeal DNA Polymerase D but Not DNA Polymerase B Is Required for Genome Replication in Thermococcus kodakarensis. J. Bacteriol. 2013, 195, 2322-2328. [CrossRef] [PubMed]

52. Raynard, S.; Sung, P. Assay for human Rad51-mediated DNA displacement loop formation. Cold Spring Harb. Protoc. 2009, 2009, 5120. [CrossRef] [PubMed]

53. Gasteiger, E.; Hoogland, C.; Gattiker, A.; Duvaud, S.; Wilkins, M.R.; Appel, R.D.; Bairoch, A. Protein Identification and Analysis Tools on the ExPASy Server. In The Proteomics Protocols Handbook; Walker, J.M., Ed.; Humana Press: Totowa, NJ, USA, 2005; pp. 571-607. ISBN 978-1-58829-343-5. 
54. Meslet-Cladière, L.; Norais, C.; Kuhn, J.; Briffotaux, J.; Sloostra, J.W.; Ferrari, E.; Hübscher, U.; Flament, D.; Myllykallio, H. A Novel Proteomic Approach Identifies New Interaction Partners for Proliferating Cell Nuclear Antigen. J. Mol. Biol. 2007, 372, 1137-1148. [CrossRef] [PubMed]

55. Sauguet, L.; Raia, P.; Henneke, G.; Delarue, M. Shared active site architecture between archaeal PolD and multi-subunit RNA polymerases revealed by X-ray crystallography. Nat. Commun. 2016, 7, 12227. [CrossRef] [PubMed]

56. Sun, Y.; McCorvie, T.J.; Yates, L.A.; Zhang, X. Structural basis of homologous recombination. Cell. Mol. Life Sci. 2019, 77, 3-18. [CrossRef]

57. Seitz, E.M.; Brockman, J.P.; Sandler, S.J.; Clark, A.J.; Kowalczykowski, S.C. RadA protein is an archaeal RecA protein homolog that catalyzes DNA strand exchange. Genes Dev. 1998, 12, 1248-1253. [CrossRef]

58. Del Val, E.; Nasser, W.; Abaibou, H.; Reverchon, S. RecA and DNA recombination: A review of molecular mechanisms. Biochem. Soc. Trans. 2019, 47, 1511-1531. [CrossRef]

59. Atwell, S.X.; Migliozzi, D.; Dupont, A.; Viovy, J.-L.; Cappello, G. Structural transitions and mechanochemical coupling in the nucleoprotein filament explain homology selectivity and Rad51 protein cooperativity in cellular DNA repair. Phys. Rev. E 2020, 101, 032407. [CrossRef] [PubMed]

60. De Vlaminck, I.; Van Loenhout, M.T.; Zweifel, L.; Blanken, J.D.; Hooning, K.; Hage, S.; Kerssemakers, J.; Dekker, C. Mechanism of Homology Recognition in DNA Recombination from Dual-Molecule Experiments. Mol. Cell 2012, 46, 616-624. [CrossRef]

61. Liu, J.; Sneeden, J.; Heyer, W.-D. In vitro assays for DNA pairing and recombination-associated DNA synthesis. In DNA Recombination; Humana Press: Totowa, NJ, USA, 2011; Volume 745, pp. 363-383.

62. Ito, K.; Murayama, Y.; Takahashi, M.; Iwasaki, H. Two three-strand intermediates are processed during Rad51-driven DNA strand exchange. Nat. Struct. Mol. Biol. 2017, 25, 29-36. [CrossRef]

63. Sheng, D.; Zhu, S.; Wei, T.; Ni, J.; Shen, Y. The in vitro activity of a Rad55 homologue from Sulfolobus tokodaii, a candidate mediator in RadA-catalyzed homologous recombination. Extremophiles 2007, 12, 147-157. [CrossRef]

64. Graham, W.J.; Rolfsmeier, M.L.; Haseltine, C. An archaeal RadA paralog influences presynaptic filament formation. DNA Repair 2013, 12, 403-413. [CrossRef]

65. Rolfsmeier, M.L.; Haseltine, C. The RadA Recombinase and Paralogs of the Hyperthermophilic Archaeon Sulfolobus solfataricus. Methods Enzymol. 2018, 600, 255-284. [CrossRef] [PubMed]

66. Tavares, E.M.; Wright, W.D.; Heyer, W.-D.; Le Cam, E.; Dupaigne, P. In vitro role of Rad54 in Rad51-ssDNA filament-dependent homology search and synaptic complexes formation. Nat. Commun. 2019, 10, 4058. [CrossRef]

67. Knadler, C.; Rolfsmeier, M.; Vallejo, A.; Haseltine, C. Characterization of an archaeal recombinase paralog that exhibits novel anti-recombinase activity. Mutat. Res. Fundam. Mol. Mech. Mutagen. 2020, 821, 111703. [CrossRef] [PubMed]

68. Wardell, K.; Haldenby, S.; Jones, N.; Liddell, S.; Ngo, G.; Allers, T. RadB acts in homologous recombination in the archaeon Haloferax volcanii, consistent with a role as recombination mediator. DNA Repair 2017, 55, 7-16. [CrossRef] [PubMed]

69. Andriuskevicius, T.; Kotenko, O.; Makovets, S. Putting together and taking apart: Assembly and disassembly of the Rad51 nucleoprotein filament in DNA repair and genome stability. Cell Stress 2018, 2, 96-112. [CrossRef] [PubMed]

70. Hogrel, G.; Lu, Y.; Laurent, S.; Henry, E.; Etienne, C.; Phung, D.K.; Dulermo, R.; Bossé, A.; Pluchon, P.-F.; Clouet-D'Orval, B.; et al. Physical and functional interplay between PCNA DNA clamp and Mre11-Rad50 complex from the archaeon Pyrococcus furiosus. Nucleic Acids Res. 2018, 46, 5651-5663. [CrossRef]

71. Formosa, T.; Alberts, B.M. DNA synthesis dependent on genetic recombination: Characterization of a reaction catalyzed by purified bacteriophage T4 proteins. Cell 1986, 47, 793-806. [CrossRef]

72. Patel, M.; Jiang, Q.; Woodgate, R.; Cox, M.M.; Goodman, M.F. A new model for SOS-induced mutagenesis: How RecA protein activates DNA polymerase V. Crit. Rev. Biochem. Mol. Biol. 2010, 45, 171-184. [CrossRef]

73. Madru, C.; Henneke, G.; Raia, P.; Hugonneau-Beaufet, I.; Pehau-Arnaudet, G.; England, P.; Lindahl, E.; Delarue, M.; Carroni, M.; Sauguet, L. Structural basis for the increased processivity of D-family DNA polymerases in complex with PCNA. Nat. Commun. 2020, 11, 1-12. [CrossRef] [PubMed] 
74. Kreuzer, K.N.; Brister, J.R. Initiation of bacteriophage T4 DNA replication and replication fork dynamics: A review in the Virology Journal series on bacteriophage T4 and its relatives. Virol. J. 2010, 7, 358. [CrossRef] [PubMed]

(c)

(C) 2020 by the authors. Licensee MDPI, Basel, Switzerland. This article is an open access article distributed under the terms and conditions of the Creative Commons Attribution (CC BY) license (http://creativecommons.org/licenses/by/4.0/). 